\title{
Utilization of Fluted Pumpkin (Telfairia occidentalis) Seed Milk for the Production of Textured Vegetable Protein
}

\author{
M. Ameka Hamilton China, Olumati N. Precious, and Friday Owuno
}

\section{ABSTRACT}

\begin{abstract}
Milk from soybean and fluted pumpkin seeds were processed to produce textured vegetable proteins (tofu) using two coagulants namely: lime and calcium sulphide. The textured vegetable proteins were analyzed for their proximate composition and sensory properties. Proximate composition of the texture vegetable proteins revealed a range of 13.67-15.04\% moisture, 1.39-3.51\% ash, $16.56-21.32 \%$ fat, $34.75-48.00 \%$ crude protein, $6.64-14.21 \%$ crude fibre and $4.34-16.22 \%$ carbohydrate. Soymilk curd coagulated with calcium sulphide had higher ash and protein contents while fluted pumpkin seed milk curd coagulated with calcium sulphide had significantly $(p<0.05)$ higher fat and crude fibre contents. There was no significant $(p<0.05)$ difference in the crude protein, moisture, and carbohydrate content of the textured vegetable proteins. Mean sensory scores of the curds showed a range of 4.40-6.70 for colour, 5.05-6.50 for aroma, 3.20-5.20 for taste, 3.956.15 for texture, 3.55-6.25 for flavour and 4.18-6.65 for overall acceptability. The sensory result showed that soybean milk coagulated with calcium sulphide was the most preferred sample for all sensory attributes. Fluted pumpkin milk coagulated with calcium sulphide also had sensory attributed comparable with the of soybean milk coagulated with calcium sulphide. Mean sensory scores of fluted pumpkin seed milk and soybean milk curds coagulated with calcium sulphide were more preferred than the samples coagulated with lime juice. The study therefore recommends the use of fluted pumpkin seed milk coagulated with calcium sulphide for the production of tofu with sensory attributes and nutrient content comparable with soybean tofu.
\end{abstract}

Keywords: Fluted Pumpkin, Soybean, Coagulants, Textured vegetable proteins.

\section{INTRODUCTION}

Fluted pumpkin (Telfairia occidentalis) is a perennial plant belonging to the family Cucurbitaceae [1]. It is one of the most popular vegetables widely cultivated in Nigeria especially by the South-Southerners and South Easterners. It grows up to $10 \mathrm{~m}$ with stems having branching tendrils while the fruits are pale green of about 3-10 m weight and seeds 3$5 \mathrm{~cm}$ in diameter [2]. It is called Ugu by the Igbo's, Ugwu by the Yoruba's, and Nkong by the Ibibio's/Efik's. According to Alozie et al. [3], the full-fat fluted pumpkin seed contains $3.00 \%$ moisture, $35.58 \%$ fat, $5.25 \%$ ash, $10.20 \%$ protein, $3.50 \%$ crude fibre and $42.27 \%$ carbohydrate. The seeds of fluted pumpkin can be eaten raw, boiled or roasted and can also be used to produce a baked product [4]. Fluted pumpkin seeds can be processed into flour and mixed with other flour for the production of bakery products such as cakes and biscuits [5], [6]. Fluted pumpkin seed is very rich in oil, especially unsaturated fatty acids which forms $61 \%$ of the oil. The seeds are also a good source of minerals such as calcium, iron and zinc and vitamins like B, C, D, E, and K required in protein (TVP).
Submitted : May 18, 2021

Published : July 06, 2021

ISSN: $2684-1827$

DOI: $10.24018 /$ ejfood.2021.3.4.81

\section{Ameka Hamilton China*}

Department of Home Science and Management, Rivers State University, Nkpolu Oroworukwo, Port Harcourt, Rivers State, Nigeria.

(e-mail: mercy4china@gmail.com)

Olumati N. Precious

School of Secondary Education (Vocational), Department of Home Economics, Federal College of Education (Technical), Omoku, Rivers State, Nigeria. (e-mail: preciousolumati76@gmail.com) Friday Owuno

Department of Food Science and Technology, Rivers State University, Nkpolu Oroworukwo, Port Harcourt, Rivers State, Nigeria.

(e-mail: owunofriday@gmail.com)

*Corresponding Author

human nutrition [7], [8]. As a result of the nutritional content of fluted pumpkin seeds, the aqueous extract of the seeds have a potential to be used for the production textured vegetable

Textured vegetable proteins are 'food products made from edible plant protein. They are characterized by a structural integrity and recognizable texture, such that each unit will resist hydration in cooking and other procedures used in preparing the food for consumption. The production of textured vegetable proteins especially from legumes has been reported by Omohimi et al. [9] to be a promising option in mitigating the problem of protein -malnutrition as they are good alternatives to animal protein which could be used to substitute meat in foods. They are also referred to as meat analogous since they compete favourably with beef in terms of flavour and chewiness. The production involves converting a flour-type material into one which has a meatlike texture [10]. The resulting protein is called textured vegetable protein which provides chewiness and fibrous character. The common raw material used for the production of textured vegetable proteins is soybean flour. Soybean is commonly used due to its high nutritional content over other 
legume crops. Products from soybean protein have been used as functional food ingredients in most food category accessible to the consumers. However, one problem that may be limiting the use of soybean in rural communities for the production of texturized vegetable proteins may be unavailability or unaffordability; hence the need to utilize other legume such as fluted pumpkin as an alternative to soybean.

Recent developments in human nutrition concerns sourcing for cheap and available protein foods. This becomes necessary as animal protein is more expensive and beyond the reach of many low-income earners in most communities in Nigeria. Soybeans which has been used as an alternative source of protein to animal protein, has also become expensive, and the demand for protein in diet is increasing. There is therefore a need to seek for alternative legume to soybeans, and the best option is to utilize fluted pumpkin seeds milk for production of textured vegetable protein. Also, most foods consumed by households are starchy foods such as tubers and cereals based- diets households coupled with insufficient supply of animal protein as a result of oil exploration in most communities and the present economic situation in Nigeria. It becomes necessary to utilize other crop from the legume group such as fluted pumpkin, which is readily available, cheap, and nutritious for textured vegetable protein and to enhance food and nutritional stability in order to reduce the challenge of protein malnutrition in households.

A lot of legume especially soybeans have been utilized for the production of textured vegetable protein. However, the use of fluted pumpkin seeds in textured vegetable protein has not been emphasized. The utilization of fluted pumpkin seeds in textured vegetable protein will be a way of diversifying the preparation of fluted pumpkin seeds thereby encouraging its utilization in households and reduce over dependence on soybeans, as the seeds will serve as an alternative to soybeans. Therefore, this study aims at utilizing fluted pumpkin seed milk for the production of textured vegetable protein and evaluating the proximate and sensory properties of the product.

\section{MATERIALS AND METHODS}

\section{A. Raw Materials}

Freshly harvested and matured fluted pumpkin fruits were obtained from a local farm in Akwa Ibom State, Nigerian. Soybean, salt, pepper, stock powder, vegetable oil and lime were purchased from Mile (3) market, Port-Harcourt. Other chemical and regents were collected from the analytical laboratory of Food Science and Technology, Rivers State University, Port Harcourt.

\section{B. Processing of Fluted Pumpkin milk}

Milk was processed from fluted pumpkin fruits using the method of Banigo et al. [11] while the modified methods of Anozie et al. [12] was used for the production of the curds. Fluted pumpkin fruits were cut open to obtain the seeds. The seeds were separated from the pulp. Seeds with intact seed coats were washed and boiled in tap water in a covered stainless steel pot for $30 \mathrm{mins}$ to soften the seed coats. The seed coats were removed using kitchen knife sliced and wet milled using a commercial mills and sieved using chiffon cloth to obtain fluted pumpkin milk, the milk was boiled for $1 \mathrm{hr}$ to deactivate anti-nutrient. Sodium sulfate was used as coagulant to obtain fluted pumpkin milk curd. The curd was spiced, shaped, and fried to obtain textured vegetable protein.

\section{Processing of Soybean Milk}

Milk was processed from soybeans using the method of Arueya [13]. Soybeans seeds were sorted, washed, and soaked overnight. Thereafter, it was dehulled and wet milled using a commercial mill and sieved using chiffon cloth to obtain soybeans milk that was used for preparation of soybeans curd which was used as the control. The same method was used for soybean milk curd preparation. However, two coagulants calcium sulphide and lime juice were used for the soybean milk curd processing.

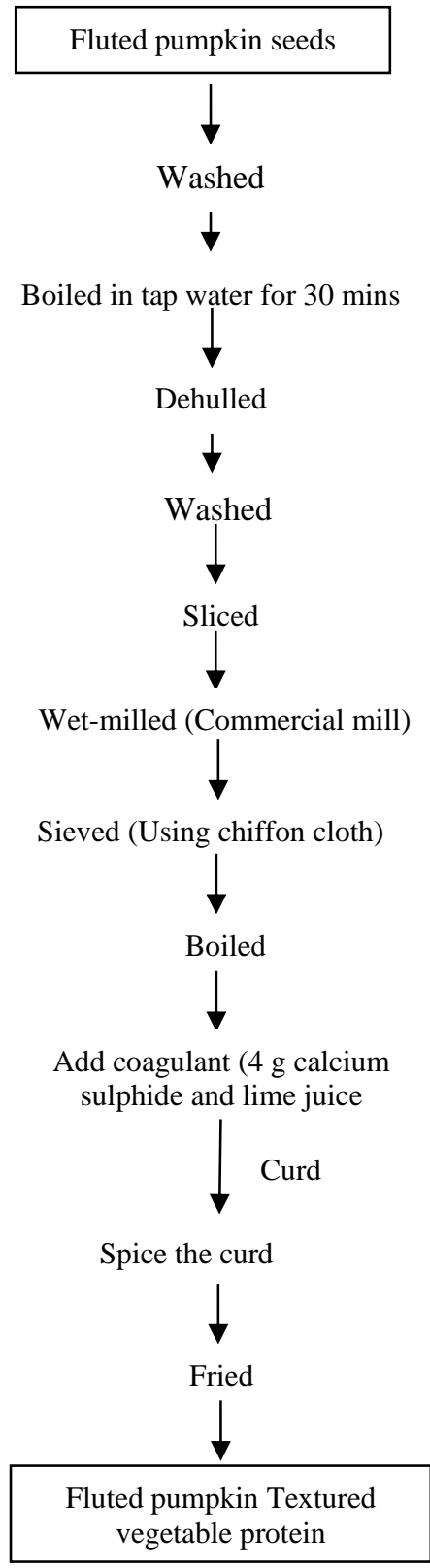

Fig. 1. Processing of fluted pumpkin textured vegetable protein. Source: Modified method Anozie et al. [12]. 


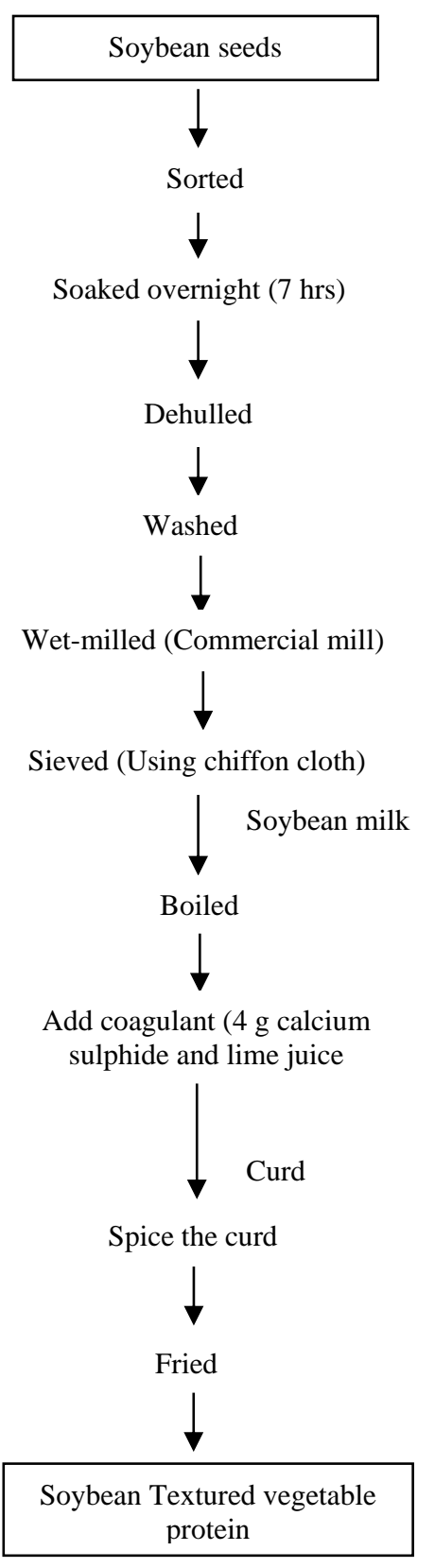

Fig. 2. Processing of soybeans textured vegetable protein. Source: Arueya [13].

TABLE I: RECIPE FOR CURD PREPARATION

\begin{tabular}{cc}
\hline Ingredients & Quantity \\
\hline Fluted pumpkin milk & 1 litre \\
Soybean milk & 1 litre \\
Fresh pepper & $25 \mathrm{~g}$ \\
Vegetable oil & $250 \mathrm{ml}$ \\
Salt & $1.5 \mathrm{~g}$ \\
Stock powder & $1.5 \mathrm{~g}$ \\
\hline
\end{tabular}

\section{Sample Formulation for Preparation}

Four samples were formulated. Fluted pumpkin milk was coagulated with $0.4 \%$ (40 ml) of calcium sulphide and $0.7 \%$ $(70 \mathrm{ml})$ of lemon juice in two separate stainless steel pots. Soybeans milk (control) was also coagulated with $0.4 \%$ (40 $\mathrm{ml})$ of calcium sulphide and $0.7 \%(70 \mathrm{ml})$ of lemon juice in two separate stainless steel pots for formation of curd that was later spiced and fried.

\section{E. Proximate composition of the Textured Vegetable Protein}

Moisture, ash, fat, crude protein and crude fibre contents of each rice flour sample was carried out according to AOAC [14] methods of analysis while carbohydrate content was evaluated using the formula below:
Total carbohydrate $(\%)=100-($ Fat $\%+$ Protein $\%+$ Moisture $\%+$ Ash $\%$ + Crude Fibre)

\section{F. Sensory Evaluation of the Curd}

The sensory attributes of the textured vegetable proteins were obtained using simple Hedonic tests as described by Iwe [15]. This was done using a twenty (20) member panel comprising of students from Food Science and Technology Department, who were familiar with textured vegetable proteins. A 9-point Hedonic scale was used where 1 and 9 represented dislike extremely and like extremely, respectively. The attributes that were evaluated include colour, texture, taste, flavour and general acceptability.

\section{G. Statistical Analysis}

Results were analyzed statistically by the analysis of variance and differences between means separated using Turkey's Multiple Comparison Test and significance accepted at $p>0.05$ level. The statistical package in MINITAB 16 computer programme was used.

\section{RESULTS AND DISCUSSION}

\section{A. Proximate Composition of Textured Vegetable Protein Produced from Fluted Pumpkin Seed Milk}

Table II shows the proximate composition of textured vegetable protein produced from fluted pumpkin seed milk. Moisture content of the textured vegetable proteins ranged from $13.26-15.04 \%$ with the lowest value (13.26\%) obtained in sample SBCB (Soybean milk- Coagulated with $0.4 \%$ Calcium Sulphide) while sample SBLD (Soybeans milkcoagulated with $0.7 \%$ lime juice) had the highest (15.04\%). There was no significant $(p>0.05)$ difference in the moisture content of the samples. Moisture content of the samples was higher when compared with the values of $7.50-8.00 \%$ reported by Obiegbuna et al. [16] for lime juice, acetic acid and $\mathrm{CaCl}_{2}$ coagulated tofu samples. The variation in the moisture content of textured vegetable proteins prepared with different coagulants from this study is probably due to the differences in gel network within the tofu particles that is influenced by different anions and its ionic strengths towards the water holding capacity of textured vegetable protein gels [17]. It may also be due to the unique coagulating properties of the coagulants used. Moisture content is of significance as it is one of the determinants of shelf-life of processed foods [18]. The moisture content of the textured vegetable proteins coagulated with calcium sulphide from this study are low enough (less than 13\%) to reduce the chance of microbial spoilage and to gurantee good storage stability. This study further suggests that textured vegetable proteins coagulated with calcium sulphide would keep longer than the samples coagulated with lime juice. According to Agoreyo et al. [19], 
low moisture content decreases the perishability and increases the shelf life of the food.

Ash content of the samples ranged from 1.39-3.51\% with sample FPCA (calcium sulphide coagulated fluted pumpkin milk) having the lowest value $(1.39 \%)$ while sample SBCB (calcium sulphide coagulated soybean milk) had the highest (3.51\%). Ash content of sample SBCB was significantly $(\mathrm{p}<0.05)$ different from sample FPCA. The presence of ash is an indication of minerals in food. This suggests that calcium sulphide coagulated soybean milk has higher mineral content than calcium sulphide coagulated fluted pumpkin milk. Ash content of the samples from this study was higher when compared to the values of $0.57 \%$ and $0.63 \%$ obtained by Rizkaprilisa and Setiadi [20] for $\mathrm{CaSO}_{4}$ and papain enzyme coagulated textured vegetable soy protein. It is however comparable with the findings of Obiegbuna et al. [16] who reported a range of 3.40-4.00\% for tofu coagulated with lime juice, acetic acid and $\mathrm{CaCl}_{2}$. The result from this study therefore shows that the textured vegetable protein produced from fluted pumpkin milk is a good source of dietary minerals needed for most of the physiological processes taking place in the body.

Fat content of the samples ranged from $16.56 \%$ in sample FPLC to $21.32 \%$ in sample FPCA. Fat content of sample FPCA was significantly $(p<0.05)$ different from all other samples. Fats (lipids) are structural components of all tissues and are indispensable for the assembly of membranes of cells and cell organelles. They are sources of essential fatty acids for the body's fat synthesis, and serve as vehicles for the absorption of fat-soluble vitamins and other precursors. Dietary fats slow gastric emptying and intestinal motility thereby prolonging the length of time food is left in the stomach - increasing the satiety values of meals. This is particularly important for infants and children due to their small stomach size [21]. The crude fat content of the textured vegetable protein make these samples contribute to meeting the daily lipid requirement of consumers. However, higher lipid content would make the product highly susceptible to rancidity [22]. Fat content of the samples are higher than the values of 7.87-15.39\% reported by Shokunbi et al. [17] for tofu coagulated with $\mathrm{CaCl}_{2}, \mathrm{MgCl}_{2}, \mathrm{MgSO}_{4}$ and alum. It is however low when compared with the values (31.50-35.20\%) obtained by Ndatsu and Olekan [22] for textured vegetable proteins coagulated with alum, effluent from pap and calcium. It is also within the range of $16.20-18.40 \%$ reported by Obiegbuna et al. [16] for acetic acid, calcium chloride coagulated soybean curds.
Crude protein content of the samples ranged from 34.75$48.00 \%$ with the lowest value $(34.75 \%)$ obtained in sample FPCA while sample B had the highest value $(48.00 \%)$. There was no significant $(p>0.05)$ difference in the crude protein content of the samples. Crude protein content of the samples is higher than the values of $19.25-26.25 \%$ reported by Obiegbuna et al. [16] for acetic acid and calcium chloride coagulated soybean curds. The values reported for protein $(34.75-48.00 \%)$ reflects the high protein content of soybeans and fluted pumpkin which makes it useful in combating protein-energy malnutrition, especially in the rural communities of developing countries. This is expected as fluted pumpkin is notable to contain significant amount of protein that is of high biological value [3]. Protein serves as the major structural components of all cells in the body, and functions as enzymes, transport carriers, and some hormones. Dietary protein is an important macronutrient in human nutrition being the source of essential amino acids for the synthesis of the body's proteins [24].

Crude fibre content of the samples ranged from 5.90$14.21 \%$ with sample SBLD having the lowest value (5.90\%) while sample FPCA had the highest $(14.21 \%)$. Crude fibre content of sample FPCA was significantly $(p<0.05)$ different from samples SBCB, FPLC and SBLD. Crude fibre content of the samples from this study is comparable with the values of $6.67-9.75 \%$ obtained by Shokunbi et al. [17] for $\mathrm{CaCl}_{2}$, $\mathrm{MgCl}_{2}, \mathrm{CaSO}_{4}, \mathrm{MgSO}_{4}$ and alum coagulated soybean curds. Crude fibre is the amount of indigestible sugars present in a food sample which has the physiological role of adding bulk to stool, and thus contribute to the maintenance of internal distensions for a normal peristaltic movement [25]. By facilitating peristalsis, dietary fibre helps to reduce many gastrointestinal diseases, serum cholesterol, risk of coronary heart disease, colon and breast cancer and hypertension [26].

Carbohydrate content of the samples ranged from 4.34$16.22 \%$ with sample FPCA having the lowest value (4.34\%) while sample SBLD had the highest $(16.22 \%)$. There was a significant $(\mathrm{p}<0.05)$ difference in the carbohydrate content of the samples. The values obtained from this study for carbohydrate is lower than the values of $22.60-28.26 \%$ obtained by Ndatsu and Olekan [22] for textured vegetable proteins coagulated with alum, effluent from pap and calcium. It is also lower than the values of $43.40-53.25 \%$ obtained by Obiegbuna et al. [16] for lime juice, acetic acid and $\mathrm{CaCl}_{2}$ coagulated tofu samples.

TABLE II: Proximate Composition (\%) of TeXtured Vegetable Protein Produced from Fluted Pumpkin Seed Milk

\begin{tabular}{ccccccc}
\hline Sample & Moisture & Ash & Crude protein & Fat & Crude fibre & Carbohydrate \\
\hline FPCA & $13.67^{\mathrm{a}} \pm 0.38$ & $1.39^{\mathrm{b}} \pm 0.14$ & $21.32^{\mathrm{a}} \pm 0.00$ & $34.75^{\mathrm{a}} \pm 0.62$ & $14.21^{\mathrm{a}} \pm 0.17$ & $4.34^{\mathrm{d}} \pm 0.66$ \\
SBCB & $13.26^{\mathrm{a}} \pm 0.21$ & $3.51^{\mathrm{a}} \pm 0.06$ & $19.34^{\mathrm{b}} \pm 0.09$ & $48.00^{\mathrm{a}} \pm 1.42$ & $6.64^{\mathrm{b}} \pm 0.03$ & $9.23^{\mathrm{c}} \pm 1.16$ \\
FPLC & $14.58^{\mathrm{a}} \pm 0.14$ & $2.98^{\mathrm{a}} \pm 0.06$ & $16.56^{\mathrm{b}} \pm 1.03$ & $45.25^{\mathrm{a}} \pm 0.28$ & $7.62^{\mathrm{b}} \pm 0.06$ & $13.03^{\mathrm{b}} \pm 0.53$ \\
SBLD & $15.04^{\mathrm{b}} \pm 2.14$ & $2.90^{\mathrm{a}} \pm 0.80$ & $18.13^{\mathrm{b}} \pm 1.62$ & $41.80^{\mathrm{a}} \pm 7.34$ & $5.90^{\mathrm{b}} \pm 1.08$ & $16.22^{\mathrm{b}} \pm 2.71$ \\
\hline
\end{tabular}

Mean values are of duplicate determinations. Mean values within a column with different superscripts are significantly different at $(\mathrm{p}<0.05)$. KEYS:

FPCA: (Fluted pumpkin milk- Coagulated with $0.4 \%$ Calcium Sulphide).

SBCB: (Soybean milk- Coagulated with $0.4 \%$ Calcium Sulphide).

FPLC: (Fluted pumpkin milk -Coagulated with $0.7 \%$ lime juice).

SBLD: (Soybeans milk- coagulated with $0.7 \%$ lime juice). 


\section{B. Sensory Properties of Textured Vegetable Protein Produced from fluted Pumpkin Seed Milk}

Table III shows the mean sensory scores of textured vegetable protein produced from fluted pumpkin seed milk and soybean milk. Colour of the textured vegetable proteins ranged from 4.40 to 6.75 with sample FPLC as the least preferred while sample SBCB was most preferred. Colour for sample FPLC was significantly $(p<0.05)$ different from all other samples while no significant $(p>0.05)$ difference existed between samples FPCA, SBCB and SBLD. Aroma of the samples ranged from 5.05-6.50 with sample FPLC as the least preferred while sample FPCA the most preferred sample. Aroma of sample FPCA was significantly $(\mathrm{p}<0.05)$ different from sample FPLC but not significantly $(p>0.05)$ different from samples SBCB and SBLD.

Taste of the samples ranged from 3.20 to 5.20 with sample FPLC as the least preferred while sample SBCB was the most preferred. Taste of sample FPLC was significantly $(\mathrm{p}<0.05)$ different from sample SBCB but not from FPCA and SBLD. The low preference for taste of the textured vegetable protein from fluted pumpkin milk could be due to the fact that matured pumpkin seeds were used in the extraction of the milk. The bitter taste arising from high polyphenol content of the matured fluted pumpkin seed milk could have influenced the taste of the final product [27]. According to Akwaowo et al. [28], tannins and polyphenols in pumpkin seeds which are responsible for bitter taste increases with age. Older and matured seeds were reported to contain very high levels of anti-nutrients which may constitute potent human poisons.

Texture of the samples ranged from 3.95 to 6.15 with sample FPLC as the least preferred while sample SBCB was the most preferred. Texture of sample FPLC was significantly $(p<0.05)$ different from sample SBCB but not from FPCA and SBLD. Flavour of the samples ranged from 3.55 to 5.35 with sample FPLC as the least preferred while sample SBLD was the most preferred. Flavour of sample FPLC was significantly $(p<0.05)$ different from all other samples while no significant $(\mathrm{p}>0.05)$ difference existed between samples FBCA, SBCB and SBLD.

Overall acceptability of the samples ranged from 4.18 to 6.65 with sample FPLC as the least preferred while sample SBLD was most preferred. Overall acceptability of sample FPLC was also significantly $(\mathrm{p}<0.05)$ different from all other samples while no significant $(p>0.05)$ difference existed between samples FBCA, SBCB and SBLD. The sensory evaluation result therefore shows that sample FBCA compares favourably with samples SBCB and SBLD for all sensory attributes.

\begin{tabular}{ccccccc}
\multicolumn{6}{c}{ TABLE III: MEAN SENSORY SCORES OF TEXTURED VEGETABLE PROTEIN PRODUCED FROM FLUTED PUMPKIN SEED MILK } \\
\hline Sample & Colour & Aroma & Taste & Texture & Flavour & Overall acceptability \\
\hline FPCA & $6.20^{\mathrm{a}} \pm 1.24$ & $6.50^{\mathrm{a}} \pm 1.76$ & $4.45^{\mathrm{a}} \pm 2.13$ & $4.85^{\mathrm{a}} \pm 1.72$ & $5.05^{\mathrm{a}} \pm 1.66$ & $5.64^{\mathrm{a}} \pm 1.43$ \\
SBCB & $6.75^{\mathrm{a}} \pm 1.58$ & $5.95^{\mathrm{a}} \pm 1.14$ & $5.20^{\mathrm{a}} \pm 1.36$ & $6.15^{\mathrm{a}} \pm 0.74$ & $6.25^{\mathrm{a}} \pm 1.29$ & $6.65^{\mathrm{a}} \pm 1.34$ \\
FPLC & $4.40^{\mathrm{b}} \pm 2.39$ & $5.05^{\mathrm{b}} \pm 2.28$ & $3.20^{\mathrm{b}} \pm 1.76$ & $3.95^{\mathrm{b}} \pm 2.23$ & $3.55^{\mathrm{b}} \pm 1.70$ & $4.18^{\mathrm{b}} \pm 1.46$ \\
SBLD & $6.70^{\mathrm{a}} \pm 1.49$ & $6.00^{\mathrm{a}} \pm 1.55$ & $4.85^{\mathrm{a}} \pm 1.98$ & $5.85^{\mathrm{a}} \pm 1.92$ & $5.35^{\mathrm{a}} \pm 1.75$ & $6.08^{\mathrm{a}} \pm 1.23$ \\
\hline
\end{tabular}

Mean values are of duplicate determinations. Mean values within a column with different superscripts are significantly different at (p <0.05). KEYS:

FPCA: (Fluted pumpkin milk- Coagulated with $0.4 \%$ Calcium Sulphide).

SBCB: (Soybean milk- Coagulated with $0.4 \%$ Calcium Sulphide).

FPLC: (Fluted pumpkin milk - Coagulated with $0.7 \%$ lime juice).

SBLD: (Soybeans milk- coagulated with $0.7 \%$ lime juice).

\section{CONCLUSION}

The result from this study has showed that an acceptable and nutritious textured vegetable protein can be produced from fluted pumpkin milk. The fluted pumpkin milk coagulated with calcium sulphide contained significantly $(p<0.05)$ higher crude protein and crude fibre content than the soybean textured vegetable protein. While the soybean milk coagulated with calcium sulphide had higher ash and fat contents. Sensory evaluation of the textured vegetable proteins showed that the soybean milk coagulated with calcium sulphide was the most preferred for all sensory attributes. The result also revealed that the textured vegetable protein produced from fluted pumpkin and coagulated with calcium sulphide was not significantly $(\mathrm{p}<0.05)$ different from textured vegetable protein produced from soybean. This therefore shows that fluted pumpkin milk coagulated with calcium sulphide can be a good substitute for soybean curd. Further studies should be carried out on the use of younger fluted pumpkin seeds for the production of textured vegetable protein.

\section{ACKNOWLEDGEMENT}

China, Mercy Ameka Hamilton would like to thank Mr. Anim Ekpo for support to accomplish this research work.

\section{REFERENCES}

[1] Kuku, A. I, Etti U.I and Ibironke, I.S (2014). Processing of Fluted Pumpkin seeds, Telfairia occidentalis (Hook F) as it affects growth performance and nutrient metabolism in rats. African Journal of Food, Agriculture, Nutrition and Development, 14(5): 39-45.

[2] Usunobun, U. and Egharebva, E. (2015). Phytochemical analysis, proximate and mineral composition and in vitro antioxidant activities in Telfairia occidentalis aqueous leaf extract. Journal of Basic and Applied Sciences, 1(1): $74-87$.

[3] Alozie, Y., Udo, A. and Orisa, C. (2017). Proximate, anti-nutrient and vitamin composition of full-fat and defatted Seed Flour of Telfairia occidentalis. Turkish Journal of Agriculture-Food Science and Technology, 5(11): 1256-1260.

[4] Giami S.Y and Barber L.I (2004). Utilization of protein concentrates from Ungerminated and germinated fluted pumpkin (Telfaria occidentalis Hook) seeds in cookie formulations Journal of the Science of Food and Agriculture 84:1901-1907.

[5] China, M.A.H., Deedam, N.J. and Olumati, P.N. (2020). Effect of fluted pumpkin seeds flour on the proximate and sensory properties of cooking banana flour biscuits and queens cake for household consumption. Research Journal of Food Science and Nutrition, 5(2): 30-34.

[6] China, M.A.H. and Ezema, P.N. (2016). Chemical analysis and organoleptic evaluation of snacks from composite flour of Dioscorea 
alata and Telfairia occidentalis seeds flour. International Journal of Agriculture Innovation and Research, 4(4): 655-660.

[7] Kayode, A.A.A. and Kayode, O.T. (2011). Some Medicinal Values of Telfairia occidentalis: A Review. American Journal of Biochemistry and Molecular Biology, 1: 30-38.

[8] Udoh, I. E. (2017). Nutritional and chemical properties of fluted pumpkin (Telfairia occidentalis) seed flours, protein concentrates and isolates. Nigerian Journal of Agriculture, Food and Environment, 13(1):206-213.

[9] Omohimi C.I., Sobukola P.O.,Sarafadeen K.O., and Sanni L.O.(2013).Effect of Process Parameters on the Proximate Composition, Functional and Sensory Properties of Extruded Meat Analogue from Mucuna Bean Seed Flour. World Academy of Science, Engineering and Technology, 76: 1-10.

[10] Adedokun, I. I., Onyeneke, E. N., Nwokeke, B. C., Obiloma, A. and Ogbonna, P. C (2017). Proximate composition and sensory properties of meat analogue from blends of plant protein sources of bambara nut and African breadfruit seeds. Nigerian Journal of Agriculture, Food and Environment, 13(4):98-102.

[11] Banigo, E.B., Kiin-Kabari, D.B. and Owuno, F. (2015). Physicochemical and sensory evaluation of soy/carrot drinks flavoured with beetroot. African Journal of Food Science and Technology, 6(5): 136-140.

[12] Anozie, G., O., China, M., A. and Belaya, E, A. (2014). Sensory Evaluation and Proximate Composition of Snacks Produced from Campsite Flour of Dioscorea alata and Telfairia occidentalis Seeds Flours, Journal of Home Economic Research, 20: 100-108.

[13] Arueya, G.I., Owoseni, B.S and Olatoye, K.K (2017). Development of texturized vegetable protein from lima bean (Phaseolus lunatus) and African oil bean seed [pentaclethrama crophylla (benth)]: optimization approach. Journal of food technology 21(1): 61-68.

[14] AOAC. (2012). Official Methods of Analysis of the Association of Official Analytical Chemists, $20^{\text {th }}$ ed.

[15] Iwe MO (2010). Handbook of Sensory Methods and Analysis. Rojoint Communication Services Ltd. Enugu. pp. 75-78.

[16] Obiegbuna, J.E., Morah, G.N. and Ishiwu, C.N. (2014). Comparison of yields and physicochemical properties of lime juice with acetic acid and calcium chloride coagulated soybean curds. Journal of Food and Nutrition Sciences, 2(3): 58-62.

[17] Shokunbi, O.S., Babajide, O.O., Otaigbe, D.O. and Tayo, G.O. (2011). Effect of coagulants on the yield, nutrient and anti-nutrient composition of Tofu. Archives of Applied Science Research, 3 (3):522-527.

[18] Agunbiade, S.O., Ojezele, M.O., and Alao, O.O. (2015). Evaluation of the nutritional, phytochemical compositions and likely medicinal benefits of Vernomia amygdalina, Talinum triangulare and Ocimum basilicum leafy-vegetables. Advances in Biological Research, 9(3): 447-42.

[19] Agoreyo, B.O., Akpiroroh, O., Orukpe, O.A., Osaweren, O.R. and Owabor, C.N. (2011). The effects of various drying methods on the nutritional composition of Musa paradisiaca, Dioscorea rotundata and Colocasia esculenta. Asian Journal of Biochemistry, 6(6): 458-464.

[20] Rizkaprilisa, W. and Setiadi, S. (2018). Comparative study of CaSO4 and papain enzyme as coagulants in the tofu production. Indonesian Food and Nutrition Progress, 15(2): 79-84.

[21] FAO (2010). Fats and fatty acids in human nutrition: report of an expert consultation. FAO Food and Nutrition Paper, 91, 10-14 Nov. 2008. Geneva.

[22] Ndatsu, Y. and Olekan, A.A. (2012). Effects of different types of coagulants on the nutritional quality of tofu produced in the Northern parts of Nigeria. World Journal of Dairy and Food Sciences, 7(2): 135141.

[23] Odibo, F.J.C., Ezeaku, E.O. and Ogbo, F.C. (2008). Biochemical change during fermentation of Prosopis Africana seeds for ogiri-okpei production. Journal of Industrial Microbiology and Biotechnology, 35: 947-952.

[24] Onyeike, E.N., Anyalogbu, E.A. and Monanu, M.O. (2015). Effect of Heat Processing on the proximate composition and energy values of African Walnut (Plukenetia conophora) and African Elemi (Canariumschweinfurthii) consumed as Masticatories in Nigeria. International Journal of Scientific and Technology, 4(8): 295-301.

[25] Akinyele B.J. and Oloruntoba, O.S. (2013) Comparative studies on Citrullus vulgaris, Citrullus colocynthis and Cucumeropsis mannii for Ogiri` production. British Journal of Microbiology Research, 3 (1): 118.

[26] Ganong W.F. (2003) Review of Medical Physiology. (21st ed.), McGraw Hill. Companies Inc., New York, pp. 316-318.

[27] Lesschaeve, I. and Noble, A.C. (2005). Polyphenols: factors influencing their sensory properties and their effects on food and beverage preferences. American Journal of Clinical Nutrition, 81(1): 330-335.

[28] Akwaowo, E.U., Ndon, B.A. and Etuk, E.U. (2000). Minerals and antinutrients in fluted pumpkin (Telfairia occidentalis Hook). Food Chemistry, 70(2): 235-240.

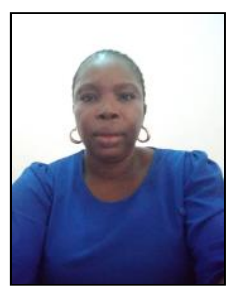

Dr. China Mercy Ameka Hamilton is a LECTUER in the Department of Home Science and Management, Rivers State University, Port Harcourt. Her area of specialization is Home Management. She is a registered member of the Home Economics Research Association of Nigeria (HERAN) and Home Economic Profesional Association of Nigeria (HEPAN). She has many undergrduate supervisons to her credit and has published many papers in highly reputable National and International Journals. 